\title{
Investigation of the structure and proteolytic activity of papain in aqueous miscible organic media
}

\author{
Carlos R. Llerena-Suster ${ }^{\mathrm{a}}$, Carla José ${ }^{\mathrm{b}}$, Sebastián E. Collins ${ }^{\mathrm{c}}$, Laura E. Briand ${ }^{\mathrm{b}}$, Susana R. Morcelle ${ }^{\mathrm{a}, *}$ \\ a Laboratorio de Investigación de Proteínas Vegetales (LIPROVE), Depto. de Cs. Biológicas, Fac. Cs. Exactas, Universidad Nacional de La Plata, Calle 47 y 115, La Plata, Argentina

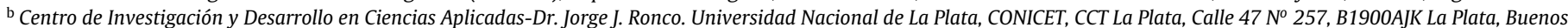 \\ Aires, Argentina \\ ${ }^{\mathrm{c}}$ Instituto de Desarrollo Tecnológico para la Industria Química INTEC, Universidad Nacional del Litoral, CONICET, Güemes 3450,3000 Santa Fe, Santa Fe, Argentina
}

\section{A R T I C L E I N F O}

\section{Article history:}

Received 6 September 2011

Received in revised form

30 September 2011

Accepted 7 October 2011

Available online 19 October 2011

\section{Keywords:}

Papain

Aqueous-organic media

Catalytic stability

Structural stability

Thermal stability

Fluorescence spectroscopy

ATR-FTIR spectroscopy

\begin{abstract}
A B S T R A C T
The stability of papain was studied in aqueous-organic mixtures by means of residual proteolytic activity along with various spectroscopic analyses (fluorescence and ATR-FTIR combined with isotopic exchange with $\left.\mathrm{D}_{2} \mathrm{O}\right)$. The investigated systems contained 1 or $10 \%(\mathrm{v} / \mathrm{v})$ of an aqueous buffered solution $(\mathrm{pH} 8.0)$ in acetonitrile $(\mathrm{ACN})$, methanol $(\mathrm{MeOH})$ or dimethyl formamide (DMF). The results evidenced that papain retained almost all its catalytic activity after $24 \mathrm{~h}$ of incubation in the presence of ACN, and a more compact conformation of the enzyme was detected. Papain suffered an important loss of enzymatic activity (ca. $80 \%$ ) after $24 \mathrm{~h}$ incubation in $\mathrm{MeOH}$ although, no global conformational change and minor secondary structure rearrangements were detected. This observation suggests that somehow the active site region was altered. On the other hand, papain suffered a complete inactivation when exposed to those media containing DMF. Fluorescence analyses revealed that an irreversible conformational change took place after $24 \mathrm{~h}$ incubation, and a moderate increase in $\beta$-sheet and $\beta$-turn structures was the most relevant finding when secondary structure was analyzed. The evidences demonstrated that the organic solvents induce a more rigid and compact structure of papain regardless of the organic:buffer ratio investigated. In turn, these modifications affect the active catalytic site in the particular case of MeOH and DMF. These findings were in agreement with the thermo-stability of the enzyme performed after heating at $353 \mathrm{~K}$ in all the studied media, that is the presence of ACN did not substantially affect the secondary structure of papain. Nevertheless, the $\alpha$-helix domain demonstrated to be less thermally stable than the $\beta$-sheet domain, turning into aggregated structures after heating, especially in the presence of MeOH and DMF.
\end{abstract}

(c) 2011 Elsevier Ltd. All rights reserved.

\section{Introduction}

Papain (EC 3.4.22.2) is a cysteine endopeptidase that is found in latex of the papaya plant (Carica papaya). It is widely used in food, detergent, textile and pharmaceutical industries due to its versatility and easy production. However, when a substantial quantity of papain with high purification degree is needed, a wild-type recombinant form of the enzyme would be recommended in order to avoid shortcomings such as the use of a lot of raw material, dependence on the climatic conditions for growth, and methods used for its extraction and purification among others. Cloning and expression of papain has been made in many different systems; however, the production of recombinant papain in a sustainable fashion is still under study [1,2].

\footnotetext{
* Corresponding author.

E-mail address: morcelle@biol.unlp.edu.ar(S.R. Morcelle).
}

In this context, the influence of the operational conditions of industrial processes on the enzymatic activity, the effect of different factors (such as temperature, and exposure to stabilizing and denaturing agents, among others) on its conformation and function are currently a topic of intensive studies. These investigations are mainly based on the fact that papain is a model cysteine peptidase, since its structure is well established and therefore, a considerably amount of data are available [3-6].

This enzyme catalyzes the synthesis of amides and esters, hydrolysis of macromolecules, and asymmetric hydrolysis in a variety of reaction media such as aqueous, organic, biphasic organic-aqueous media and ionic liquids. In this context, papain is suitable as a biocatalyst in the synthesis of fine chemicals and pharmaceuticals and an interesting alternative to make greener processes. The conditions in which these reactions take place might affect, to a more or less extent, papain structure and thus, its catalytic activity. Several studies revealed that the exposure to different environments, denaturing and stabilizing agents causes many folding/unfolding transition states that affect its secondary 
Table 1

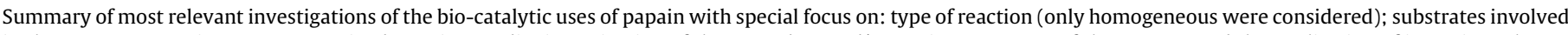

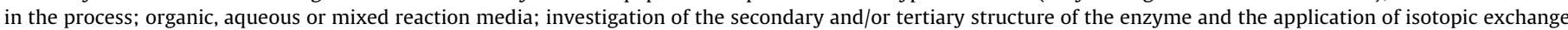
for Amide I investigation.

\begin{tabular}{|c|c|c|c|c|c|}
\hline Type of reaction & Substrates & Medium & Structure investigation & Isotopic exchange & Ref \\
\hline $\begin{array}{l}\text { Protected dipeptide } \\
\text { Boc-Gly-Phe-OMe } \\
\text { synthesis }\end{array}$ & $\begin{array}{l}\text { Boc-Gly-OH } \\
\text { Phe-OMe } \\
\text { Phe-OBz }\end{array}$ & $\begin{array}{l}\text { Trichloroethylene, } \mathrm{CCl}_{4} \text {, } \\
\text { ciclopentanone, benzene, } \\
\text { toluene, } n \text {-heptane, Tween } 80\end{array}$ & No & No & [7] \\
\hline $\begin{array}{l}\text { Z-Gly-Phe- } \mathrm{NH}_{2} \\
\text { synthesis }\end{array}$ & $\begin{array}{l}\text { Z-Gly-OH } \\
\text { Phe- } \mathrm{NH}_{2}\end{array}$ & $\begin{array}{l}\text { Tert-butanol with solid } \\
\text { acid-base buffers }\end{array}$ & No & No & [8] \\
\hline None & None & $\begin{array}{l}\text { Aqueous sodium dodecyl } \\
\text { sulfate }\end{array}$ & $\begin{array}{l}\text { Circular dichroism, } \\
\text { fluorimetry, FTIR, UV-vis, } \\
\text { NMR, dynamic light scattering }\end{array}$ & Yes & [9] \\
\hline Hydrogenation & $\begin{array}{l}\text { Methyl } \\
\text { 2-acetamidoacrylate }\end{array}$ & Aqueous buffer ( $\mathrm{pH} 7$ ) & No & No & [10] \\
\hline Hydrolysis & Casein & $\begin{array}{l}\text { Aqueous, ethanol; } 1,4 \text { dioxane; } \\
\text { acetonitrile, tetrahydrofuran }\end{array}$ & $\begin{array}{l}\text { Fluorescence, circular } \\
\text { dichroism }\end{array}$ & No & [11] \\
\hline Asymmetric hydrolysis & $\begin{array}{l}\text { D,L-p- } \\
\text { Hydroxyphenylglycine } \\
\text { methyl ester }\end{array}$ & $\begin{array}{l}\text { 1-Alkyl-3-methyl-imidazolium } \\
\text { cations ionic liquids }\end{array}$ & ATR-FTIR, fluorescence & No & [12] \\
\hline $\begin{array}{l}\text { Synthesis of } \\
\text { Z-L-aminoacyl- } \\
\text { antipyrine } \\
\text { amides }\end{array}$ & $\begin{array}{l}\text { Z-protected amino acid } \\
\text { esters } \\
\text { 4-Aminoantipyrine }\end{array}$ & $\begin{array}{l}\text { Aqueous-organic, biphasic } \\
\text { media }\end{array}$ & No & No & [13] \\
\hline Hydrolysis & Z-Arg-AMC & $\begin{array}{l}0-90 \%(\mathrm{v} / \mathrm{v}) \text { aqueous ethanol, } \\
\text { acetonitrile, tetrahydrofuran }\end{array}$ & $\begin{array}{l}\text { Fluorescence, circular } \\
\text { dichroism }\end{array}$ & No & [14] \\
\hline Hydrolysis & Casein & $\begin{array}{l}n \text {-Propanol-NaClaq, } \\
\text { hexane/water, PEG/phosphate } \\
\text { biphasic }\end{array}$ & No & No & [15] \\
\hline Hydrolysis & $\begin{array}{l}\text { Bovine serum albumin } \\
\text { (BSA), ovalbumin, } \\
\text { casein, } \\
N \text {-benzoyl-L-arginine } \\
\text { ethyl ester }\end{array}$ & Aqueous buffered & No & No & [16] \\
\hline
\end{tabular}

and tertiary structures [5-8]. In this context, Table 1 summarizes the most relevant investigations concerning the uses of papain as a biocatalyst in the homogeneous fashion along with the substrates involved in the process, nature of the reaction media, and investigation of the secondary and/or tertiary structure of the enzyme [9-18]. Focusing on infrared studies, the application of isotopic exchange for Amide I investigation is highlighted.

A detailed literature search also demonstrates that there are few investigations presenting structure-stability-activity correlations for the application of papain as biocatalyst in reactions occurring in mixtures of aqueous-organic media. Simon and coworkers demonstrated that the tertiary structure of papain is influence by water-miscible solvents and hence its activity [13]. Further investigations of the authors proved that the tolerance towards organic solvents is increased when the enzyme is chemically modified with monocarboxylic and dicarboxylic acids [16]. More recently, Wang and coworkers investigated the modifications of the protein conformation of papain due to the impact of ionic liquids [14]. The authors reported the second derivative of the ATR-FTIR spectra of the Amide I region of papain as a sensitive probe of protein conformation. Ghosh investigated conformational modifications due to the interactions of papain with an anionic surfactant in aqueous medium by analyzing the secondary structure through FTIR after the exchange of the molecules of $\mathrm{H}_{2} \mathrm{O}$ by $\mathrm{D}_{2} \mathrm{O}$ [11]. In this sense, the isotopic exchange avoids the strong $\mathrm{O}-\mathrm{H}$ bending absorption at $1644 \mathrm{~cm}^{-1}$ of $\mathrm{H}_{2} \mathrm{O}$ which overlaps with the infrared signal of the Amide I. The $\mathrm{O}-\mathrm{D}$ bend is shifted about $400 \mathrm{~cm}^{-1}$ to lower frequency as compared to the $\mathrm{O}-\mathrm{H}$ bend, thus leaving an useful window free of absorptions in the Amide I region [19]. The usefulness of ATR-FTIR in combination with $\mathrm{H}_{2} \mathrm{O} / \mathrm{D}_{2} \mathrm{O}$ exchange for secondary structure determination of papain was firstly described by Goormaghtigh et al. [20].

The present investigation focuses on the determination of the structure and stability of papain extracted from papaya latex using methanol $(\mathrm{MeOH})$, acetonitrile $(\mathrm{ACN})$ and dimethylformamide
(DMF) containing $1 \%$ and $10 \%$ of added water. The behavior of the protease in aqueous buffer of $\mathrm{pH}=8.0$ was also examined and established as the reference condition, since the conformation that the enzyme exhibits at this $\mathrm{pH}$ is considered as the most favorable for peptide synthesis in the presence of organic solvents [21]. In this context, biological stability was evaluated through the determination of its proteolytic activity. Additionally, intrinsic and extrinsic fluorescence spectroscopy and attenuated total reflexion infrared spectroscopy (ATR-FTIR) were used in order to obtain evidences of effect of the solvents both at the surface and at the bulk of the enzyme. Finally, the effect of the solvents on the thermal stability of papain was also addressed through in situ ATR-FTIR analysis.

\section{Materials and methods}

\subsection{Chemicals}

Papain was purified to mass spectrometry degree from dry latex of Carica papaya fruits obtained in Jujuy, Argentina, as described previously [22,23]. Casein (Hammarsten type) from bovine milk, tris-(hydroximethyl)-aminomethane (Tris), cysteine, 8-aniline-1-naphthalene-sulfonic acid (ANS) and $\mathrm{N}$-acetyl-L-Trp ethy ester (ATrEE) were Sigma Aldrich products. Coomassie Brilliant Blue G-250 was obtained from Bio-Rad. Acetonitrile $(\mathrm{ACN})$ and methanol $(\mathrm{MeOH})$ were obtained from Baker. $N, N$-dimethylformamide (DMF) was from Merck. Additional chemicals were obtained from commercial sources and were of the highest purity available.

\subsection{Stability assays}

The mixtures of organic solvent and buffered aqueous solution were composed by 1 and $10 \%$ of aqueous boric acid-sodium borate buffer $0.1 \mathrm{M} \mathrm{pH} \mathrm{8.0,} \mathrm{and} 99$ and $90 \%$ of a miscible organic solvent such as, ACN, MeOH and DMF. Papain $(0.4 \mathrm{mg})$ was contacted with $1.00 \mathrm{ml}$ of each of those organic solvent-buffer mixtures and incubated at $37^{\circ} \mathrm{C}$ with orbital shaking ( $180 \mathrm{rpm}$ ) during 1 and $24 \mathrm{~h}$. Then, the samples were centrifuged $\left(10 \mathrm{~min}, 4^{\circ} \mathrm{C}, 3600 \times g\right)$ and the supernatant containing the organic-aqueous mixture was discarded. Each pellet was dried under vacuum and redissolved in $0.5 \mathrm{ml}$ of Tris- $\mathrm{HCl}$ buffer $0.1 \mathrm{M} \mathrm{pH} 8.0$, and the residual activity was tested using casein as substrate according to the method reported by Priolo et al [24]. Protein concentration of each sample was determined according to Bradford's method [25]. Specific enzymatic activity was expressed in an arbitrary unit (Ucas/mg 
protein), being 1 Uca the increment of one absorbance unit at $280 \mathrm{~nm}$ produced by the soluble peptides resulting from casein breakdown per minute of assay.

\subsection{Fluorescence spectroscopy determinations}

Papain was incubated as described above in mixtures of aqueous buffer (Tris- $\mathrm{HCl}$ $0.1 \mathrm{M} \mathrm{pH} \mathrm{8.0)}$ and the organic solvents in the proportions already indicated. The samples obtained after incubation in the organic-aqueous mixtures were further diluted in the $0.4-0.7 \mu \mathrm{M}$ range with buffer in order to perform the analysis through fluorescence spectroscopy. This analysis was performed on a Shimazdu RF 1501 spectrofluorimeter (slit width equal to $10 \mathrm{~nm}$ ) at room temperature.

\subsubsection{Intrinsic fluorescence}

Papain was excited at $292 \mathrm{~nm}$ and the emission was recorded at $310-500 \mathrm{~nm}$. The determination of the direct effect of the solvents (with the exception of $\mathrm{MeOH}$ ) on Trp fluorescence and a model compound (ATrEE) was assayed at a concentration of $1.7 \mu \mathrm{M}$ of papain in the aqueous buffer and a concentration of $0.6 \mu \mathrm{M}$ of papain in the mixtures of aqueous-organic solvents. Fluorescence spectra of the different organic-aqueous solvents were also recorded as blanks. Resulting emission spectra were the mean of five consecutive scans.

Additionally, the reversibility of the effect of the solvents on papain was investigated. In this context, the organic solvents (with the exception of DMF) were evaporated under vacuum at room temperature and the resulting sample of papain was redissolved in Tris- $\mathrm{HCl}$ buffer $0.1 \mathrm{M} \mathrm{pH}$ 8.0. In the particular case of DMF was removed by centrifugation, and further washing with water the precipitate; the remaining solid was redissolved in Tris- $\mathrm{HCl}$ buffer as described for the other samples. Fluorescence spectra were determined as indicated above.

\subsubsection{Extrinsic fluorescence}

The investigation of the effect of the organic-aqueous mixtures on the ANS fluorescence was performed by exciting the samples with a radiation of $380 \mathrm{~nm}$ and recording the emission in the $400-550 \mathrm{~nm}$ range. The optimal molar ratio of papain and ANS in Tris- $\mathrm{HCl}$ buffer $0.1 \mathrm{M} \mathrm{pH} 8.0$ obtained was in the range of $0.2-1.0 \mu \mathrm{M}$ and $65 \mu \mathrm{M}$, respectively. The samples were prepared by evaporating the solvents (with the exception of DMF) and redissolving the solid in aqueous buffer as described before. DMF was eliminated as mentioned above. Emission spectra were the mean of five consecutive scans.

Additionally, the measurement of the fluorescence resonance energy transfer (FRET) from protein tryptophan to ANS was investigated. In this context, papain was irradiated at $292 \mathrm{~nm}$ and the emission spectra were collected in the range of $300-550 \mathrm{~nm}$. The emission spectra were the mean of five consecutive scans.

\subsection{Isotopic exchange with $\mathrm{D}_{2} \mathrm{O}$ and ATR-FTIR analysis}

The isotopic exchange of water molecules by $\mathrm{D}_{2} \mathrm{O}$ molecules allows investigating the Amide I signal $\left(1700-1600 \mathrm{~cm}^{-1}\right)$ without the interference of the bending vibration of $\mathrm{O}-\mathrm{H}$ species that typically appears at $1640 \mathrm{~cm}^{-1}$. The $\mathrm{H}-\mathrm{D}$ isotopic exchange of water molecules of all papain samples was performed by contacting the sample with $100 \mu$ l of deuterium oxide ( $>$ >99\%) under a vigorous stirring for $10 \mathrm{~min}$ and further incubation overnight at room temperature. The completeness of the isotopic exchange was investigated by taking the infrared spectra of the mixture of papain- $\mathrm{D}_{2} \mathrm{O}$ (papain recovered from buffer medium) overnight into the ATR cell. The sample was analyzed once every 5 min during the first $60 \mathrm{~min}$ and once every hour along the night.

The exchanged samples were analyzed through FTIR in an ATR liquid flowthrough in situ cell that is heated with an external jacket with re-circulating water (Pike Technologies). The analysis was performed dispersing the liquid mixture described above over the ATR crystal. The crystal used was a $45^{\circ}$ trapezoidal $\mathrm{ZnSe}$ whose dimensions were $80 \mathrm{~mm} \times 10 \mathrm{~mm} \times 4 \mathrm{~mm}$, providing 10 internal reflections at the liquid/crystal interface (penetration depth $=1.66 \mu \mathrm{m}$ for $n_{2}=1.4$ at $1000 \mathrm{~cm}^{-1}$ ) and a cutoff spectral range at $650 \mathrm{~cm}^{-1}$. A Nicolet 8700 FTIR spectrometer with a MCT-A cryogenic detector was used to acquire the spectra $\left(0.5-4 \mathrm{~cm}^{-1}\right.$ resolution, 100-250 scans). The spectrometer and the mirrors that direct the radiation towards the cell are continuously purged with dry air (from a Parker Balston generator) in order to eliminate the contribution of $\mathrm{CO}_{2}$ and water vapor from the spectra. The quantitative analysis of the individual component bands of the Amide I was performed with a special peak fitting module of Origin 4.1. The identification and wavenumbers of the individual components of the Amide I were obtained through the second derivative analysis of the infrared signal corresponding to the Amide I $\left(1700-1600 \mathrm{~cm}^{-1}\right)$. The curve fitting of the Amide I was performed by iterative adjustment of the relative height, width and relative ratios of Lorentzian functions of the individual component bands until the line shape of the Amide I calculated by the program was judged to be approximately the same as the experimental spectrum by least squares. The integrated area under each component band, after the last iteration, was calculated as a percentage of the total Amide I area, and this value was taken to be the percentage of the particular secondary structure present in the protein.

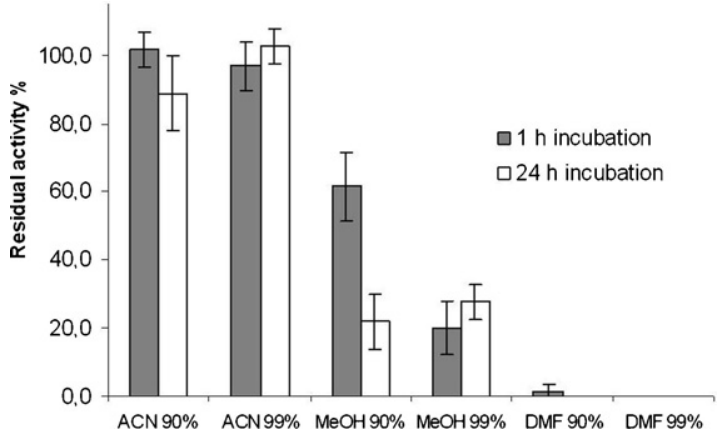

Fig. 1. Proteolytic residual activity of papain incubated in different aqueous-organic mixtures [90 and 99\% (v/v) organic solvent/aqueous buffer $\mathrm{pH}$ : 8.0].

2.4.1. Investigation of the thermal stability through ATR-FTIR analysis

The samples were heated in situ from room temperature to $353 \mathrm{~K}$ in steps of $10 \mathrm{~K}$ in the ATR-FTIR cell after being exchanged with $\mathrm{D}_{2} \mathrm{O}$. The temperature was maintained at $353 \mathrm{~K}$ for $30 \mathrm{~min}$ in order to unequivocally assess the effect of extended heating on the secondary structure of the enzyme. The equipment was the one described in the previous section.

\section{Results and discussion}

Papain has a molecular structure consisting in two domains of roughly equal size, namely $\mathrm{L}$ (left), which consists on amino acids 10-111 and 208-212, and domain R (right) is composed by amino acids $1-9$ and 112-207. The two domains are separated by a deep cleft which contains the active site, a catalytic triad composed by Cys25 (L domain), His159 (R domain) and Asn175 (R domain) residues. The $\mathrm{L}$ domain is mainly $\alpha$-helical, whereas antiparallel $\beta$-sheet is the predominant structure of the R domain [26]. It is known that the $S_{2}$ subsite of the active site is selective to hydrophobic amino acid [27], although its specificity has generally been proclaimed as broad [28]. In this context, the presence of organic solvents broadens enzymatic specificity towards non-coded amino acids or even molecules that are not amino acids [15,29,30]. Additionally, the presence of organic solvents in the reaction media favors the catalytic action of papain (among other peptidases) on the formation of diverse amide/ester bonds [31-34]. An insight of papain structural behavior in selected media containing high content of water miscible organic solvents (being ACN and DMF aprotic and $\mathrm{MeOH}$ weakly protic, the three of them having similar polarity) would allow to obtain fundamental information concerning molecular structure-activity relationships in order to understand the bio-catalytic properties of papain in this particular aspect of biotechnology.

\subsection{Effect of the organic-aqueous media in the hydrolytic activity}

Papain was incubated in the presence of high contents (90 and $99 \%, \mathrm{v} / \mathrm{v}$ ) of $\mathrm{ACN}, \mathrm{MeOH}$ and DMF, and the remaining proteolytic activity towards casein was proved after 1 and $24 \mathrm{~h}$ of incubation (Fig. 1). Remarkably ACN, at such high proportions seemed not to alter significantly papain activity. It is interesting to point out that $\mathrm{ACN}$ is one of the most used organic solvents in peptide synthesis catalyzed by peptidases due to both the high stability of peptidases activity in ACN as well as the solubility of substrates and products in ACN or ACN-containing mixtures [21,35-37].

In contrast, the incubation of papain in $\mathrm{MeOH}$ containing media decreases its residual activity. Moreover, Fig. 1 shows that higher the alcohol content the lower the activity of papain. This observation correlates with the fact that the proportion of $\mathrm{MeOH}$ never exceeds a concentration of $30 \%(\mathrm{v} / \mathrm{v})$ when is used as a co-solvent in coupling reactions towards amino acid derivatives [15,38]. However, immobilized papain in Sephadex G-50 was found to be highly 
Table 2

Effect of the different solvents on papain ( $24 \mathrm{~h}$ of incubation in each media) and ATrEE fluorescence parameters.

\begin{tabular}{|c|c|c|c|c|}
\hline \multirow[t]{2}{*}{ Solvent } & \multicolumn{2}{|c|}{ Papain } & \multicolumn{2}{|c|}{ ATrEE } \\
\hline & $\lambda_{\max }$ & $I_{350 / 330}$ & $\lambda_{\max }$ & $I_{350 / 330}$ \\
\hline Aqueous buffer pH 8.0 & 343 & 1.06 & 350 & 1.49 \\
\hline ACN 90\% & 333 & 0.82 & 338 & 0.91 \\
\hline ACN 99\%a & 330 & 0.77 & 332 & 0.79 \\
\hline ACN $90 \%$ & 340 & 1.04 & - & - \\
\hline ACN $99 \%$ & 342 & 1.09 & - & - \\
\hline $\mathrm{MeOH} 90 \%$ & 342 & 1.04 & - & - \\
\hline $\mathrm{MeOH} 99 \%$ & 345 & 0.97 & - & - \\
\hline DMF $90 \%$ & 332 & 0.76 & 336 & 0.86 \\
\hline DMF 99\%a & 332 & 0.71 & 336 & 0.83 \\
\hline DMF 90\% & 334 & 0.88 & - & - \\
\hline DMF 99\%b & 334 & 0.84 & - & - \\
\hline
\end{tabular}

a Fluorescence parameters in the presence of organic solvents.

b Conformational reversibility assays of papain after being incubated in organic solvents for $24 \mathrm{~h}$ and redissolved in aqueous buffer for fluorescence determinations.

active for esterification of a variety of amino acid derivatives in reaction media containing $95 \%(\mathrm{v} / \mathrm{v}) \mathrm{MeOH}$, revealing the importance of the immobilization of enzymes to improve their stability in organic media [39].

In the present investigation, DMF was tested since several amino acids and peptide derivatives commonly used for hydrolytic and synthetic reactions are highly soluble in this solvent. For these particular reactions, final concentrations of DMF are usually lower than $70 \%(\mathrm{v} / \mathrm{v})$ [40-42]. In fact, the catalytic activity of papain exposed to DMF drastically diminishes and is suppressed upon exposure to $99 \%(v / v)$ of DMF after $1 \mathrm{~h}$ of incubation (see Fig. 1 ).

\subsection{Effect of the organic-aqueous media in the protein's conformation}

The following sections present the investigation of the structural conformation of papain through the determination of the maximum emission wavelength $\left(\lambda_{\max }\right)$ and the maximum intensity $\left(I_{\max }\right)$ of the fluorescence produced by the fluorophore residue tryptophan Trp. These measurements are an indication of the modification of the polarity of the microenvironment the Trp residue $[14,15]$.

Moreover, ATrEE was used as a model compound in order to discern how the polarity of the organic-aqueous media influences the protein conformation in the vicinity of the Trp residues $[15,43]$. Thus, the fluorescence spectra of ATrEE and papain samples were recorded in order to assess the maximal emission wavelength $\left(\lambda_{\max }\right)$ upon exposure to the various solvent-aqueous mixtures. The high polarity of water and its ability to form hydrogen bonds with ATrEE result in a maximum emission at $350 \mathrm{~nm}$. On the other hand, the emission maximum of ATrEE in ACN and DMF shifted to shorter wavelengths since their polarities are lower than water and are unable to form hydrogen bonds due to their aprotic nature. The addition of $10 \%$ of water to ACN produced a slight blue shift of the model compound when compared with ACN containing $1 \%$ of water. In contrast, this effect was not observed for DMF (see $\lambda_{\max }$ of ATrEE in Table 2).

Papain in aqueous buffer ( $\mathrm{pH}$ 8.0) showed a maximum emission at $343 \mathrm{~nm}$. The difference with the $\lambda_{\max }$ exhibited by ATrEE is basically due to the complex contribution of the papain Trp residues which is in turn related to the neighboring protein groups of each Trp. In this context, papain has five Trp residues, two of them in the $\alpha$-helical segments of the L domain: one of them is partially exposed (Trp69), whereas Trp26 is more internal but its environment is not completely hydrophobic. The other three Trp residues are in the D domain, Trp7 in a helical segment, partially exposed to the solvent and surrounded by various hydrophobic residues; Trp177 is very exposed in a random coil region, and Trp181 is buried inside the protein as part of a $\beta$-turn structure [26].

The maximum emission of papain shifted to shorter wavelengths in the presence of $90 \%$ ( $\lambda_{\max }$ equals to $333 \mathrm{~nm}$ ) and $99 \%$ ACN-aqueous media ( $\lambda_{\max }$ equals to $330 \mathrm{~nm}$ ). The results evidence that the higher the ACN content the higher the blue shift. On the other hand, there is a correspondence in the shifts of the wavelength emission maxima for both papain and ATrEE when similar compositions of $\mathrm{ACN}$-aqueous media are compared regardless of the time of incubation ( $1 \mathrm{~h}$ or $24 \mathrm{~h}$ ). In fact, the $\Delta \lambda$ equals to $10 \mathrm{~nm}$ and $12 \mathrm{~nm}$ for papain and $\mathrm{ATrEE}$ in a $90 \% \mathrm{ACN}$-aqueous mixture while, $\Delta \lambda$ is $13 \mathrm{~nm}$ and $18 \mathrm{~nm}$ for papain and ATrEE in a $99 \%$ ACN-aqueous mixture. This behavior rather than being attributed to a change in solvent polarity is an evidence of slightly more buried Trp residues.

A similar blue shift was observed upon exposure to DMFaqueous mixtures. In this case, an emission at $332 \mathrm{~nm}$ was obtained after $24 \mathrm{~h}$ incubation regardless of the composition of the organic-aqueous mixture. In this occasion, $\lambda_{\max }$ was $337 \mathrm{~nm}$ after $1 \mathrm{~h}$ of incubation in both solvent mixtures (data not shown). Similarly as discussed above for ACN-aqueous mixtures, the difference registered between $\lambda_{\max }$ for ATrEE and papain exposed to DMF-aqueous mixtures indicated that the shift in the maximum fluorescence emission is produced not only due to the change in solvent polarity, but also to buried Trp residues inside the enzyme structure. These changes in the conformation of papain upon contacting the organic-aqueous mixture are gradual since the shifts of the $\lambda_{\max }$ observed after $1 \mathrm{~h}$ of incubation increases after $24 \mathrm{~h}$ of incubation.

Table 2 also shows the intensity ratio at 350 and $330 \mathrm{~nm}\left(I_{350 / 330}\right)$ which is a measurement of the protein's unfolding being the higher the intensity ratio $I_{350 / 330}$ the higher the unfolding of the protein [44]. In general, this parameter showed lower values for papain exposed to organic-aqueous mixture than for papain in buffer media. This observation indicates that the Trp residues are buried into more hydrophobic regions of the protein leading to a more compact structure.

\subsubsection{Reversibility of the conformational changes: surface hydrophobicity}

The reversibility of the structural changes of papain in organic-aqueous media described above was investigated by extracting the protein from the organic environment and dissolving it in the aqueous buffer solution (Tris- $\mathrm{HCl} 0.1 \mathrm{M} \mathrm{pH} 8.0$ ). As can be seen in Table 2, this was the only measurement able to be performed under a $\mathrm{MeOH}$ containing media due to the high intrinsic fluorescence of such alcohol.

The results presented in Table 2 indicate that the values of $\lambda_{\max }$ of papain exposed to either to $\mathrm{MeOH}$-aqueous or $\mathrm{ACN}$-aqueous mixtures goes back to the values expected in a buffer media $(\sim 342 \mathrm{~nm})$. However, when papain was in contact with DMF and redissolved in aqueous buffer, the blue shift of $\lambda_{\max }$ persisted. There is no doubt that the conformational changes of papain detected by intrinsic fluorescence were reverted by placing the protein in an aqueous environment when the cosolvents were $\mathrm{ACN}$ and $\mathrm{MeOH}$, but these changes were irreversible in the case of DMF. In this last case, the Trp residues are buried inside a less polar protein surrounding, resulting in an inactive enzyme.

The ANS selectively binds to hydrophobic surface sites of the protein therefore, was used as a probe to detect the exposed hydrophobic residues of papain after eliminating the solvent and redissolving the protein in buffer. The presence of Trp in the vicinity of those hydrophobic regions was monitored by FRET-ANS. The fluorescence spectra of papain in buffer $0.1 \mathrm{M}$ Tris- $\mathrm{HCl} \mathrm{pH} 8.0$ without previous exposure to an organic solvent were taken as reference ( $\lambda_{\max }$ equals to $477 \mathrm{~nm}$ ). 

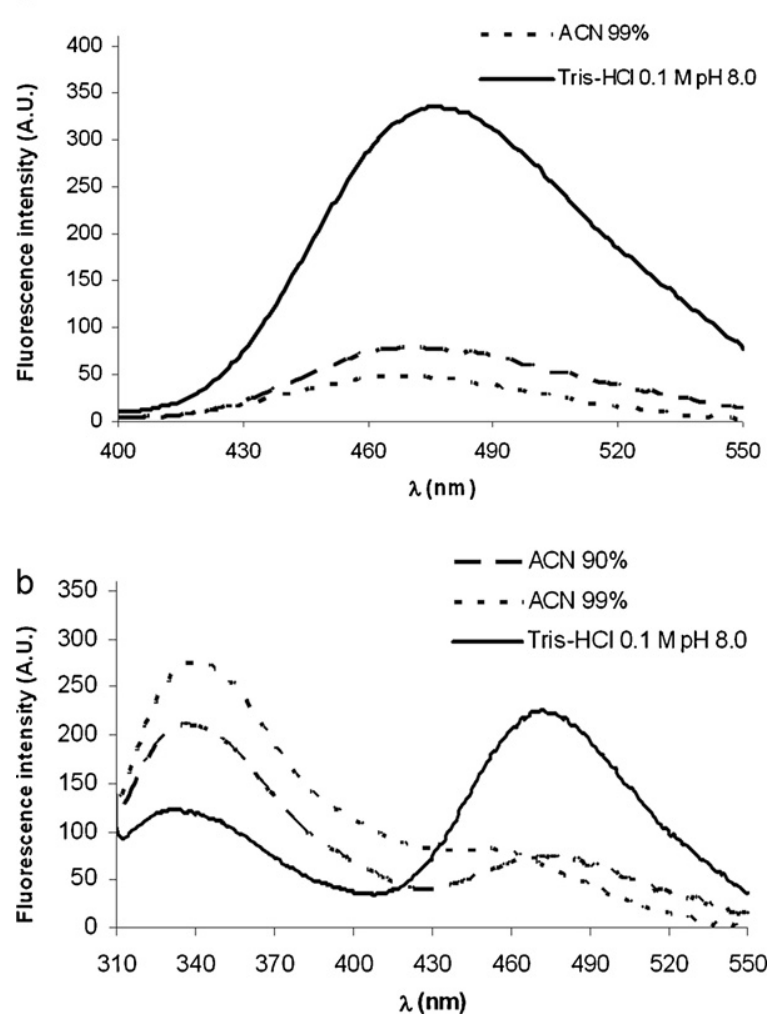

Fig. 2. (a) Fluorescence spectra of ANS-papain after protease incubation in ACN-containing mixtures. (b) FRET-ANS spectra of papain after incubation in ACNcontaining mixtures

Fig. 2a shows that the fluorescence emission of papain exposed to both $90 \%$ and $99 \%$ ACN-aqueous mixtures are markedly less intense than papain in the reference state. The spectra also show a shift of the ANS emission maximum towards lower wavelengths. In this context, the higher the concentration of $A C N$ the lower is the wavelength of the emission maxima.

The FRET-ANS spectra revealed that the intensity of the maximum emission of $\operatorname{Trp}\left(\lambda_{\max }\right.$ in the vicinity of $340 \mathrm{~nm}$ ) was higher for papain exposed to ACN-aqueous mixtures than papain in the reference state (see Fig. 2b). On the contrary, the signal corresponding to ANS ( $\lambda_{\max }$ near $480 \mathrm{~nm}$ ) of the reference papain is more intense than the intensity of the signal corresponding to the protein incubated in the organic-aqueous mixture. These differences in the intensities of the signals evidenced that the surface Trp residues of the reference papain are able to transfer energy towards the molecules of ANS, whereas the papain exposed to the ACN-aqueous mixtures are not. The absence of ANS molecules interacting with the enzyme surface provided further evidences that the surface hydrophobic residues are buried inside the protein. Moreover, this effect is stressed when papain is incubated in the $99 \% \mathrm{ACN}$-aqueous mixture, as expected.

The exposure of ANS to the $\mathrm{MeOH}$-aqueous mixtures also produced a blue shift of the $\lambda_{\max }$ emission of ANS as observed in Fig. 3a. Again, the intensity of the signal of the reference papain is lower than the intensity of papain exposed to the organic-aqueous mixtures. The FRET-ANS analysis showed a higher energy transfer from Trp residues towards ANS than the behavior observed for $\mathrm{ACN}$-aqueous mixtures (see Fig. 3b). Again, the results reveal that the papain exposed to the $\mathrm{MeOH}$-aqueous mixtures suffers slight conformational changes. On the other hand, insoluble protein aggregates were formed during papain incubation with the $\mathrm{MeOH}$-aqueous mixtures. However, Bradford's assay
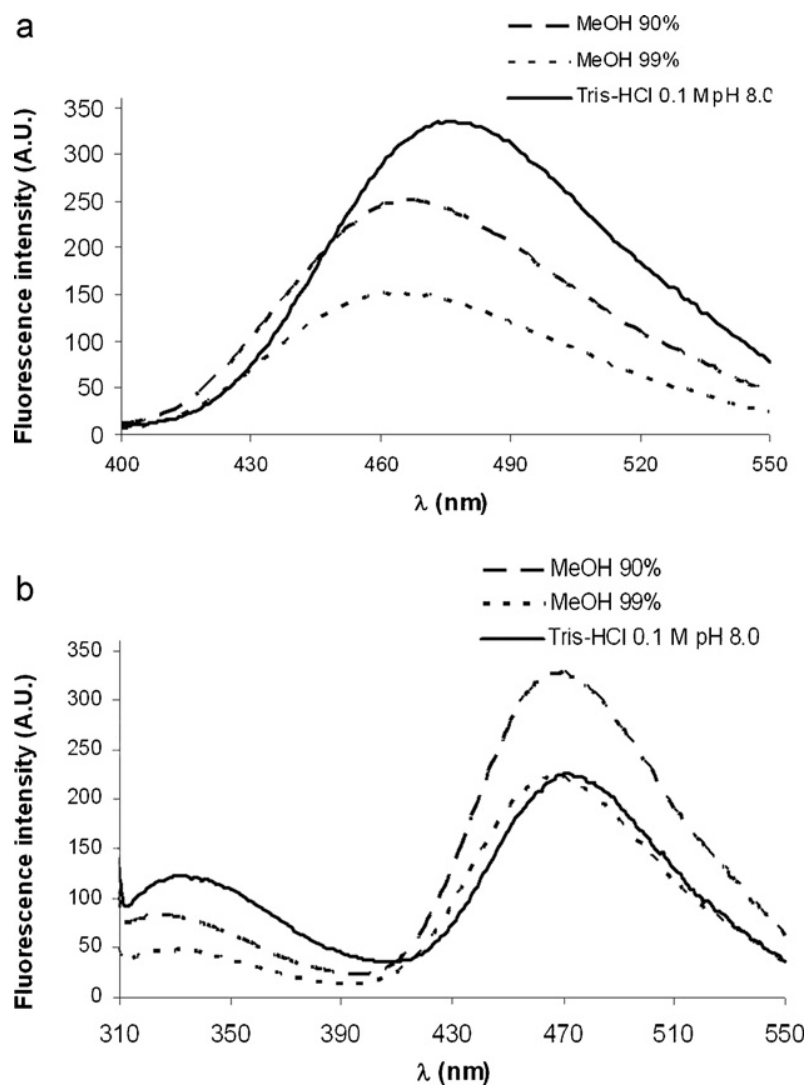

Fig. 3. (a) Fluorescence spectra of ANS-papain after protease incubation in $\mathrm{MeOH}$-containing mixtures. (b) FRET-ANS spectra of papain after incubation in $\mathrm{MeOH}$-containing mixtures.

demonstrated that a certain amount of papain remains in the supernatant which in turn, is responsible of the proteolytic activity. In this context, the fluorescence energy transfer from Trp towards ANS demonstrates that the Trp residues of the papain that remains soluble are surrounded by an environment that results more hydrophobic than the one of the native protein.

The intensities of the maximum emission of ANS adsorbed on papain that was exposed to DMF-aqueous mixtures were higher than in the reference state as can be observed in Fig. 4a. Although, the signals shift towards lower wavelengths this behavior is not as strong as observed in ACN-aqueous mixtures. The FRET spectra presented in Fig. $4 \mathrm{~b}$ indicate that the Trp residues are exposed in the hydrophobic surface since a complete energy transfer from Trp towards ANS molecules was observed. The results evidenced that DMF-aqueous mixtures alter the conformation of papain in such a way that Trp residues strongly interact with highly exposed hydrophobic surface sites deactivating the enzyme. Moreover, the increase of the concentration of the organic solvent and the exposure to the DMF-aqueous mixtures also increased the spreading of the modification of the conformation of papain.

\subsection{Effect of the organic-aqueous media on the secondary structure}

Fourier transform IR spectroscopy along with circular dichroism are the most commonly used spectroscopic techniques for determining the secondary structure of proteins in homogeneous conditions and also in the solid state. Moreover, such techniques are also used as a tool to determine protein folding, unfolding and misfolding [11,45]. Particularly, in situ ATR-FTIR spectroscopy in combination with $\mathrm{H}-\mathrm{D}$ exchange is even a more reliable tool to 

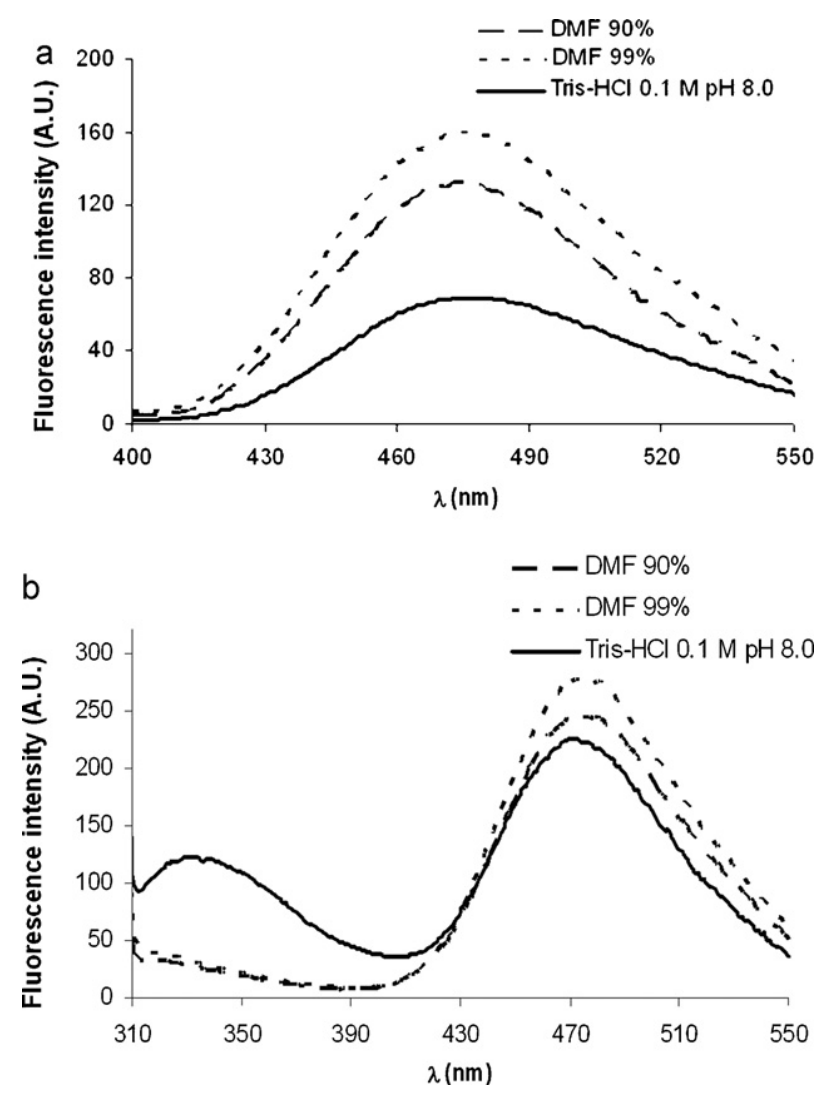

Fig. 4. (a) Fluorescence spectra of ANS-papain after protease incubation in DMF-containing mixtures. (b) FRET-ANS spectra of papain after incubation in DMFcontaining mixtures.

obtain insights on the alterations of the secondary structure of a protein induced by extrinsic factors [46].

\subsubsection{Monitoring the evolution of the isotopic exchange of papain}

The rates of the exchange of the proton of the amide bond with deuterium reflect the structural dynamics of the proteins which in turn is related to the secondary structure. A high rate of exchange implies greater flexibility and motion in the region of the protein structure where the exchange is taking place. The convenience of investigating $\mathrm{H}-\mathrm{D}$ exchange on the basis of the apparent intensity changes of the Amide II band is because this band is not adversely interfered by the adsorption bands of $\mathrm{H}_{2} \mathrm{O}$, HOD or $\mathrm{D}_{2} \mathrm{O}$ [47].

The analysis of the isotopically exchanged papain through ATRFTIR spectroscopy allowed determining the influence of the organic solvents on the secondary structure of the protein. Owing to the much lower absorption of $\mathrm{D}_{2} \mathrm{O}$ solvent in the $1700-1500 \mathrm{~cm}^{-1}$ a better signal-to-noise ratio was observed and a higher resolution spectrum was obtained. The isotopic exchange of papain that involves the replacement of the water molecules by deuterium oxide was followed overnight by taking successive ATR-FTIR spectra in the in situ mode of operation (see Section 2.4 for experimental details). The evolution of the isotopic exchange over time was evaluated through the signal known as Amide II in order to unequivocally detect the maximum possible exchange. The broad and unresolved infrared signal known as Amide II (typically at $1480-1575 \mathrm{~cm}^{-1}$ in aqueous medium) involves the out-of-phase combination of the bending vibration of the $\mathrm{N}-\mathrm{H}$ with the stretching vibration of the $\mathrm{C}-\mathrm{N}$ species of the protein. Moreover, a minor contribution of the in plane bending vibration of the $\mathrm{CO}$ and the stretching vibrations of CC and NC species appear at the same wavenumbers region $[45,48]$. The hydrogen atom of the $\mathrm{NH}$ species is relatively easy to exchange by a deuterium atom compared with the hydrogen of the amide bond that is somehow protected by hydrogen-bridge bonds and is less accessible by the solvent [48]. In this context, the $\mathrm{H}-\mathrm{D}$ exchange of the $\mathrm{NH}$ bond shifts the Amide II band towards a lower frequency, decreases the intensity and enhances the resolution of the signal [48-50]. These observations are used as evidences of the progress of the hydrogen-deuterium exchange occurred in papain in the present investigation. Fig. 5a presents a series of in situ ATR-FTIR spectra taken from the beginning up to 60 min of the isotopic exchange. Similarly, Fig. 5b shows the spectra taken after $60 \mathrm{~min}$ of the beginning of the isotopic exchange towards $18 \mathrm{~h}$ of contact between papain and $\mathrm{D}_{2} \mathrm{O}$ at room temperature. The figures show an intense band centered at $3378 \mathrm{~cm}^{-1}$ composed by the stretching vibrations of $\mathrm{O}-\mathrm{H}$ and $\mathrm{N}-\mathrm{H}$ (the so called Amide A and Amide B). The characteristic stretching vibration $v(O-D)$ at $\sim 2472 \mathrm{~cm}^{-1}$ along with the signal at $1206 \mathrm{~cm}^{-1}$ belonging to the bending vibration $\delta(0-D)$ of the oxygen-deuterium species are observed. The replacement of the hydrogen atom in the $\mathrm{O}-\mathrm{H}$ species by a deuterium atom modifies the frequency of the bending vibration band according to the equation, $v=1 / 2 \pi(k / \mu)^{1 / 2}$, where $v$ stands for the frequency; $\mathrm{k}$ stands for the bond force constant and $\mu$ stands for the reduced mass involved in the vibration. Then, the ratio of frequencies for the bending vibrations of the $\mathrm{O}-\mathrm{H}$ and $\mathrm{O}-\mathrm{D}$ species results in the following equation:

$\frac{\bar{v}(\mathrm{OH})}{\bar{v}(\mathrm{OD})}=\sqrt{\frac{\mu_{\mathrm{OD}}}{\mu_{\mathrm{OH}}}}$,

where $\bar{v}$, is the wavenumber (reciprocal of the wavelength); $\mu_{\mathrm{OH}}$ and $\mu_{\mathrm{OD}}$, are the reduced masses of the $\mathrm{OH}$ and $\mathrm{OD}$ species, respectively.

Thus, this theoretical wavenumbers ratio is equal to 1.374 , which is in agreement with the observed shift of the bending vibration of the $\mathrm{O}-\mathrm{H}$ species from $1620 \mathrm{~cm}^{-1}$ to $1206 \mathrm{~cm}^{-1}$ of the bending vibration of the $\mathrm{O}-\mathrm{D}$ species. A similar theoretical wavenumbers ratio is obtained when $\mathrm{N}-\mathrm{H}$ and $\mathrm{N}-\mathrm{D}$ species are considered:

$$
\frac{\bar{v}(\mathrm{NH})}{\bar{v}(\mathrm{ND})}=1.369
$$

Fig. 5c shows the evolution of the Amide II signal after subtracting the spectrum of the beginning of the isotopic exchange of the successive spectra up to $60 \mathrm{~min}$. Similarly, Fig. $5 \mathrm{~d}$ presents the evolution of the Amide II from $2 \mathrm{~h}$ to $18 \mathrm{~h}$ after subtracting the spectrum at $60 \mathrm{~min}$ from the successive spectra. At the very beginning of the isotopic exchange the Amide II appears as a dome centered at about $1384 \mathrm{~cm}^{-1}$ and a shoulder at $1315 \mathrm{~cm}^{-1}$ that might correspond to the Amide III (see Fig. 5a). The broad signal splits into two signals at $1411 \mathrm{~cm}^{-1}$ and $1384 \mathrm{~cm}^{-1}$ that shift to $1404 \mathrm{~cm}^{-1}$ and $1369 \mathrm{~cm}^{-1}$ when the deuteration progresses (see Fig. $5 \mathrm{~b}-\mathrm{d}$ ). In fact, the Amide II is fairly resolved after $10 \mathrm{~h}$ of isotopic exchange. The continuous increase of the infrared signal, in contrast with the observations reported in the literature, is attributed to the evaporation of the liquid film and the increasing deposition of protein on the ATR crystal.

The deuteration of the $\mathrm{NH}$ species involve in the Amide II and Amide III signals leads to the shift of the bending vibration of the $\mathrm{N}-\mathrm{D}$ species towards lower wavenumbers as was predicted before. The infrared analysis of papain purified from the latex in an aqueous medium demonstrated that the Amide II signal appears in the $1591-1482 \mathrm{~cm}^{-1}$ range in accordance with the literature. Therefore, the predicted shift towards lower wavenumbers of the Amide II signal due to the hydrogen-deuterium exchange is in a fairly good agreement with the signal centered at $1073 \mathrm{~cm}^{-1}$ observed upon deuteration (see Fig. 5a-d). 

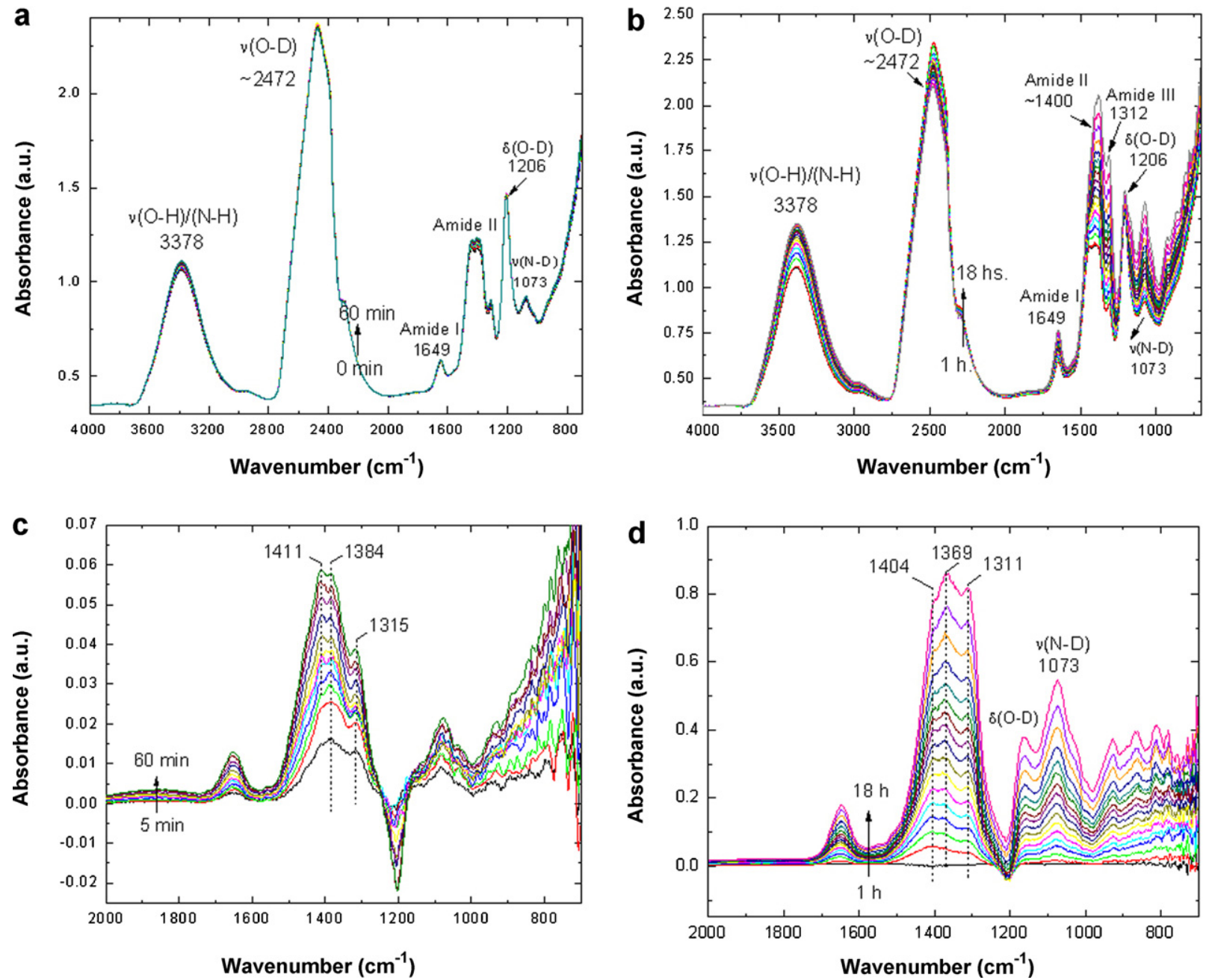

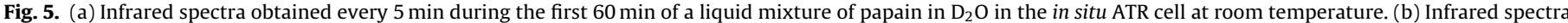

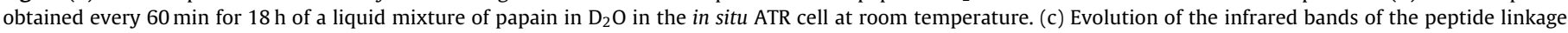

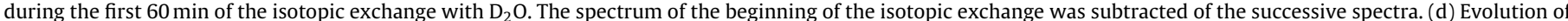

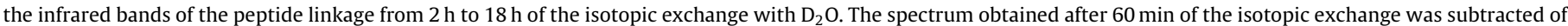
the successive spectra.

\subsubsection{Effect of the organic-aqueous media in the secondary} structure

The second derivative analysis of the Amide I (after the isotopic exchange) allowed determining the individual components of the infrared signal. An element centered at approximately $1655 \mathrm{~cm}^{-1}$ to $1658 \mathrm{~cm}^{-1}$ corresponds to the $\alpha$-helix structure.

The presence of the $\beta$-sheet structure is evidenced by a series of bands centered at about $1627 \pm 2 \mathrm{~cm}^{-1}, 1633 \pm 2 \mathrm{~cm}^{-1}$, $1638 \pm 2 \mathrm{~cm}^{-1}$ and $1697 \mathrm{~cm}^{-1}$. The signals around $1670 \pm 2 \mathrm{~cm}^{-1}$ and $1677 \pm 3 \mathrm{~cm}^{-1}$ and $1680 \pm 7 \mathrm{~cm}^{-1}$ are attributed to the $\beta$-turn structure. The presence of an unordered conformation (random coil) was detected at $1645 \pm 3 \mathrm{~cm}^{-1}[45,47,51]$. Finally, almost all the samples examined possess a weak signal at $1617 \pm 1 \mathrm{~cm}^{-1}$ assigned to intermolecular hydrogen-bonded antiparallel $\beta$-sheets, which are typically observed in protein aggregates [52]. In this context, the contribution in percentage of each secondary structure element to the Amide I signal is presented in Table 3.

Table 3 shows the deconvolved FTIR spectrum of papain in aqueous buffer at $\mathrm{pH}$ 8.0. Contents of $\alpha$-helix, $\beta$-sheet, $\beta$-turn, random coil and intermolecular aggregates are 23\%,26\%,20\%,20\% and $3 \%$, respectively. These results are in good agreement with data obtained for papain secondary structure by other authors, using ATR-FTIR and other methods as well $[13,20,26,53]$.
Papain in the presence of the $90 \%$ ACN-aqueous medium showed an increase in the $\alpha$-helix structure compared with the aqueous buffer. This result provides further evidence that the exposure of papain to ACN containing media produces the burial of the hydrophobic residues inside the protein which in turn, leads towards a secondary structure more ordered than in a buffered aqueous medium. Nevertheless, these transformations do not influence the enzymatic activity of papain suggesting that no dramatic changes would occur in the active site conformation of the protein (see Fig. 1).

Again, papain exposed to the $90 \% \mathrm{MeOH}$-aqueous mixture experiences an increase in the $\alpha$-helix content due to the conformational transition from disordered regions towards a more ordered structure (see Table 3). This observation correlates with previous investigations that also reported an increase in the $\alpha$-helix of papain in a $90 \%$ ethanol-water media [13].

Although, both papain exposed to either $90 \%$ ACN-aqueous or $90 \% \mathrm{MeOH}$-aqueous mixtures possess a similar modification of the secondary structure (both increase their $\alpha$-helix content) the enzymatic activity of papain exposed to the alcohol is considerably lower than the activity of papain exposed to the $\mathrm{ACN}$-aqueous mixtures. This observation indicates that the exposure of the hydrophobic residues (previously discussed in the FRET-ANS 
Table 3

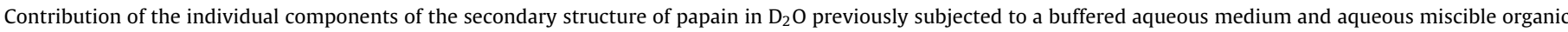
solvents containing $1 \%$ and $10 \%$ of added water at R.T.

\begin{tabular}{|c|c|c|c|c|c|}
\hline Organic-aqueous medium (\%,v/v) & $\alpha$-Helix ${ }^{\mathrm{a}}$ & $\beta$-Sheet ${ }^{b}$ & $\beta-$ Turn $^{\mathrm{c}}$ & Random coil ${ }^{\mathrm{d}}$ & Intermolecular $\beta$-sheet aggregates ${ }^{\mathrm{e}}$ \\
\hline Buffer $\mathrm{pH}=8$ & 23 & 26 & 20 & 20 & 3 \\
\hline ACN $90 \%$ & 30 & 27 & 19 & 20 & 3 \\
\hline ACN 99\% & 23 & 32 & 24 & 20 & 1 \\
\hline $\mathrm{CH}_{3} \mathrm{OH} 90 \%$ & 32 & 29 & 17 & 19 & 3 \\
\hline $\mathrm{CH}_{3} \mathrm{OH} 99 \%$ & 21 & 28 & 28 & 21 & 2 \\
\hline DMF $90 \%$ & 22 & 24 & 27 & 27 & 0 \\
\hline DMF 99\% & 17 & 39 & 9 & 22 & 13 \\
\hline
\end{tabular}

ACN, acetonitrile; DMF, dimethylformamide.

a The percentage of $\alpha$-helix corresponds to the area of the signal at $1655 \pm 3 \mathrm{~cm}^{-1}$.

b The percentage of $\beta$-sheet corresponds to the addition of the contribution of the most intense signals at $1627 \pm 2 \mathrm{~cm}^{-1}$ and $1638 \pm 2 \mathrm{~cm}^{-1}$.

c The percentage of $\beta$-turn corresponds to the addition of the contribution of the signals at $1670 \pm 2 \mathrm{~cm}^{-1}, 1677 \pm 1 \mathrm{~cm}^{-1} \mathrm{and} 1680 \pm 7 \mathrm{~cm}^{-1}$.

d The percentage of random coil corresponds to the area of the signal at $1645 \pm 3 \mathrm{~cm}^{-1}$.

e The percentage of intermolecular aggregates corresponds to the area of the signal at $1617 \pm 1 \mathrm{~cm}^{-1}$.

analysis) is actually responsible for the drop in the enzymatic activity. In fact, the exposure of the hydrophobic residues is somehow affecting the catalytically active residues of the oxoanionic hole, and thus decreasing the catalytic activity of papain as will be discussed in the following section.

It is worth noticing that the infrared analysis was performed upon exposure of papain to $\mathrm{D}_{2} \mathrm{O}$ in the liquid medium that, similarly to the buffered aqueous medium, is expected to reverse the conformational modifications due to the restitution of the hydrogen/deuterium bonds as previously discussed in Section 3.2.1. Moreover, the infrared analysis provides evidences of the bulk not the surface (as the ANS-FRET assay) of the protein therefore, it is quite reasonably to find similarity between the secondary structures of the papain exposed to buffered aqueous medium and $90 \%$ $\mathrm{ACN} / \mathrm{MeOH}$-aqueous mixtures.

Interestingly, the exposure of papain to the $90 \%$ DMF-aqueous medium increases both the random coil and the $\beta$-turn structures compared with either papain exposed to the buffered aqueous medium or to the $90 \% \mathrm{ACN} / \mathrm{MeOH}$-aqueous mixtures discussed before (see Table 3). In this context, an extended and irreversible formation of surface hydrophobic pockets evidenced through the fluorescence assays (especially the remarkable increases of the intrinsic fluorescence, ANS binding and fluorescence resonance energy transfer from Trp to ANS) might be directly related to the constitution of the unordered random coiled and $\beta$-turn structures.

The exposure to $99 \% \mathrm{ACN}$-aqueous mixture increases the contribution of the $\beta$-sheet structure compared with the enzyme that was in contact with the $90 \%$ ACN-aqueous system. However, this modification of the bulk of the enzyme or even the buring of Trp residues does not affect the bio-catalytic activity.

The secondary structure of papain exposed to both $99 \%$ $\mathrm{MeOH}$-aqueous mixture shows an increase in the unordered random coiled and $\beta$-turn structures similarly to the results observed on papain exposed to $90 \%$ DMF-aqueous mixture (see Table 3). The observation of these changes in the secondary structure correlates with the irreversible modification of the conformation already observed in the fluorescence assays (see Table 2). Moreover, the residual catalytic activity of the sample severely decreases compared with the papain exposed to $90 \%$ $\mathrm{MeOH}$-aqueous mixture (see Fig. 1). The exposure of papain to the 99\% DMF-aqueous mixture produces an increase of the aggregated structure and also, the signal of the $\beta$-sheet structure dominates the Amide I contributing with the $39 \%$ of the total area. Additionally, is worth noticing that the contribution of the $\alpha$-helix greatly diminishes a phenomenon that was not observed in the previous systems. Again, the profound alteration of the secondary structure and the irreversible modification of the enzyme's conformation correlate with the absence of residual activity of papain subjected to DMF containing media.

\subsection{Effect of the organic-aqueous media on the thermal stability}

The influence of the aqueous-organic mixtures on the thermostability of papain was investigated by heating the isotopically exchanged samples in the ATR-FTIR cell and acquiring the infrared spectra after maintaining the temperature for $10-30 \mathrm{~min}$. The thermo-stability of papain was assessed through the determination of the secondary structure of the enzyme after heating at $353 \mathrm{~K}$ for 30 min. followed by cooled down and in situ analysis. In this context, the contribution of the $\alpha$-helix, $\beta$-sheet, aggregates, $\beta$-turn and random structures to the Amide I signal was determined in order to evaluate the response of the secondary structure of the protein upon heating compared with the structure determined previously at R.T. It is worth noticing that an accurate and reliable

Table 4

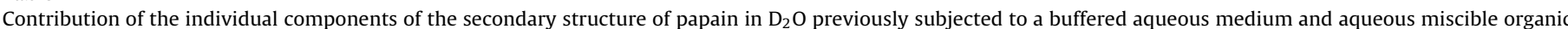
solvents containing $1 \%$ and $10 \%$ of added water and calcined at $353 \mathrm{~K}$ for $30 \mathrm{~min}$.

\begin{tabular}{|c|c|c|c|c|c|}
\hline Organic-aqueous medium (\%,v/v) & $\alpha$-Helix ${ }^{\mathrm{a}}$ & $\beta$-Sheet ${ }^{\mathrm{b}}$ & $\beta$-Turn ${ }^{\mathrm{c}}$ & Random coil ${ }^{\mathrm{d}}$ & Intermolecular $\beta$-sheet aggregates ${ }^{\mathrm{e}}$ \\
\hline Buffer $\mathrm{pH}=8$ & 22 & 23 & 19 & 27 & 8 \\
\hline ACN $90 \%$ & 21 & 19 & 18 & 30 & 11 \\
\hline ACN 99\% & 20 & 21 & 17 & 29 & 13 \\
\hline $\mathrm{CH}_{3} \mathrm{OH} 90 \%$ & 15 & 40 & 14 & 26 & 6 \\
\hline $\mathrm{CH}_{3} \mathrm{OH} 99 \%$ & 9 & 31 & 19 & 33 & 8 \\
\hline DMF $90 \%$ & 17 & 20 & 20 & 24 & 19 \\
\hline DMF 99\% & 18 & 21 & 28 & 14 & 19 \\
\hline
\end{tabular}

ACN, acetonitrile; DMF, dimethylformamide.

a The percentage of $\alpha$-helix corresponds to the area of the signal at $1655 \pm 3 \mathrm{~cm}^{-1}$.

b The percentage of $\beta$-sheet corresponds to the addition of the contribution of the most intense signals at $1627 \pm 2 \mathrm{~cm}^{-1}$ and $1638 \pm 2 \mathrm{~cm}^{-1}$.

c The percentage of $\beta$-turn corresponds to the addition of the contribution of the signals at $1670 \pm 2 \mathrm{~cm}^{-1}, 1677 \pm 1 \mathrm{~cm}^{-1}$ and $1680 \pm 7 \mathrm{~cm}^{-1}$.

d The percentage of random coil corresponds to the area of the signal at $1645 \pm 3 \mathrm{~cm}^{-1}$.

e The percentage of intermolecular aggregates corresponds to the area of the signal at $1617 \pm 1 \mathrm{~cm}^{-1}$. 
determination of the secondary structure is obtained by analyzing the infrared spectra taken after the in situ cooling down the enzyme after the thermal treatment.

The papain exposed to an aqueous buffered medium and calcined at $353 \mathrm{~K}$ maintains unaltered the contribution of the $\alpha$-helix and the $\beta$-sheet structures (compare Tables 3 and 4 ). The increase in the protein's aggregated structure observed at $353 \mathrm{~K}$ (3\% at R.T. vs $8 \%$ at $353 \mathrm{~K}$ ) is typically observed upon heating of proteins $[45,49,50]$. This observation is in agreement with the investigation of Prakash and coworkers that reported that the thermal denaturation of native papain is produced through two transitions, being the first at $T_{\mathrm{m} 1}=356 \pm 0.2 \mathrm{~K}$ [6]. The papain exposed to the ACN-aqueous mixtures decreases the contribution of the $\beta$-sheet and increases the aggregated structure; however, the $\alpha$-helix structure remains stable. Again, the papain exposed to both $\mathrm{MeOH}$ and DMF-aqueous mixtures increase the percentage of the aggregated structure but in these particular cases, an important loss of the $\alpha$-helix structure is observed (see Table 4).

Additionally, the infrared spectra of the papain exposed to the 99\% ACN-aqueous, $\mathrm{MeOH}$-aqueous and DMF-aqueous mixtures present a new signal at about $1592 \mathrm{~cm}^{-1}$ (spectra not shown). This signal is typically ascribed to the amino acids' side-chain absorption such as of tyrosine $\left(1612 \mathrm{~cm}^{-1}\right)$, glutamate $\left(1565 \mathrm{~cm}^{-1}\right)$ and arginine $\left(1587 \mathrm{~cm}^{-1}\right)[48,54]$. The observation of such signal provides further evidence of the thermal induced unfolding of the polypeptide chains that interact with each other forming strongly hydrogen-bonded aggregated structures [50].

\section{Conclusions}

The influence of organic ( $\mathrm{ACN}, \mathrm{MeOH}$ and $\mathrm{DMF}$ )-aqueous buffered mixtures on the tertiary and secondary structures of papain was investigated by means of the intrinsic tryptophan fluorescence and ATR-FTIR spectroscopy after isotopic exchange with $\mathrm{D}_{2} \mathrm{O}$. In this section, fundamental correlations between the structure of the enzyme and its residual caseinolytic activity are presented.

Interestingly, ACN-aqueous mixtures does not influence the hydrolytic activity of the enzyme regardless of the composition or the time of incubation, although more structured secondary elements (basically, $\alpha$-helix and $\beta$-sheet) and a more compact conformation than the papain in buffered aqueous medium was found [55]. There is no doubt that these results explain the widely use of ACN in the protease-catalyzed formation of peptide bonds. In contrast, the exposure of papain to the $\mathrm{MeOH}$-aqueous and DMF-aqueous mixtures decreases and even suppresses the proteolytic activity which evidences that those solvents influence the surface active sites of the enzyme. In this context, the active site of papain is composed of the residues Cys25, His158 and Asn175 located in two domains of the enzyme [7]. The L domain, which is composed of residues 10-111 and 208-212, is mainly alpha-helical, while the $\mathrm{R}$ domain with residues $1-9$ and $112-207$ is mainly made up of anti-parallel $\beta$-sheet structure therefore, the papain active site involves residues from both $\mathrm{L}$ and $\mathrm{R}$ domains and a minor change in the domain-domain interaction would affect the enzyme activity [5]. On the other hand, previous investigations reported in the literature demonstrated that such domains behave as separated polypeptides in terms of denaturation/unfolding processes [7]. The present investigation demonstrates that the papain exposed to $90 \%$ and $99 \% \mathrm{ACN}$-mixtures increases the $\alpha$-helix and $\beta$-sheet, respectively but does not influences de catalytically active residues since the bio-catalytic activity remains unaltered. This observation allows to conclude that the domain-domain interaction and hence, the active surface sites are not affected upon exposure to ACN. Nevertheless, the $\mathrm{MeOH}$-aqueous and $\mathrm{DMF}$-aqueous mixtures produce a profound distortion of the domain-domain interaction leading to a dramatic decrease in the bio-catalytic activity. Again, it is important to recall that the main chain atoms of the $\mathrm{R}$ domain compose a sheet that surrounds a large barrel like cavity in the interior of the domain, which is filled with hydrophobic side chains [7]. Now, according to the ANS-FRET analysis the hydrophobic packing is exposed on the enzyme's surface that in turn, causes a distortion of the secondary structure that is a modification of the bulk structure. In fact, MeOH-aqueous and DMF-aqueous mixtures modify the papain that is an essentially $\alpha$-helix/ $\beta$-sheet type of enzyme, towards an $\alpha$-helix $/ \beta$-sheet/random coiled (partially active) and a $\beta$-sheet/aggregated enzyme (completely inactive) enzyme. The secondary structure of papain exposed to the buffered aqueous medium and the ACN-aqueous mixtures is not affected upon heating up to $353 \mathrm{~K}$.

The $\alpha$-helix domain of papain exposed to $\mathrm{MeOH}$ and DMF-aqueous mixtures is surprisingly less thermally stable than the $\beta$-sheet domain. In this context, the $\alpha$-helix degrades towards aggregated structures upon heating.

\section{Acknowledgements}

Authors acknowledge Comisión Nacional de Investigación Científica y Tecnológica (CONICET, PIP N ${ }^{\circ} 11420100100150$ ), Universidad Nacional de La Plata (UNLP, Projects X-576 and 11-X-485) and Agencia de Promoción Científica y Técnica (ANPCyT, PICT 02224 and PICT Redes 729/06) for financial support. CRLS and CJ were awarded CONICET fellowship. SEC, LEB and SRM are members of CONICET Researcher Career.

\section{Appendix A. Supplementary data}

Supplementary data associated with this article can be found, in the online version, at doi:10.1016/j.procbio.2011.10.003.

\section{References}

[1] Choudhury D, Roy S, Chakrabarti C, Biswas S, Dattagupta JK. Production and recovery of recombinant propapain with high yield. Phytochemistry 2009;70:465-72, and references therein.

[2] Ramjee MK, Petithory JR, McElver J, Weber SC, Kirsch JF. A novel yeast expression/secretion system for the recombinant plant thiol endoprotease propapain. Prot Eng 1996;9:1055-61, and references therein.

[3] Rawlings ND, Barrett AJ. Introduction: the clans and families of cysteine peptidases. In: Barrett A, Rawlings ND, Woessner JF, editors. Handbook of proteolytic enzymes. London: Academic Press; 2004. p. 1051-71.

[4] Sangeetha K, Abraham TE. Chemical modification of papain for use in alkaline medium. J Mol Catal B: Enzym 2006;38:171-7.

[5] Chamani J, Heshmati M. Mechanism for stabilization of the molten globule state of papain by sodium $n$-alkyl sulfates: spectroscopic and calorimetric approaches. Colloid Interface Sci 2008;322:119-27.

[6] Sathish HA, Kumar PR, Prakash V. Mechanism of solvent induced thermal stabilization of papain. Int J Biol Macromol 2007;41:383-90.

[7] Sathish HA, Kumar PR, Prakash V. The differential stability of the left and right domains of papain. Process Biochem 2009;44:710-6.

[8] Edwin F, Jagannadham MV. Sequential unfolding of papain in molten globule state. Biochem Biophys Res Commun 1998;252:654-60.

[9] Feliu JA, de Mas C, Lopez-Santin J. Studies on papain action in the synthesis of Gly-Phe in 2-liquid-phase media. Enzyme Microb Technol 1995;17:882-7.

[10] Theppakorn T, Kanasawud P, Halling PJ. Effect of solid-state buffers on the catalytic activity of papain in low water media. Enzyme Microb Technol 2003;32:828-36.

[11] Ghosh S. Conformational study of papain in the presence of sodium dodecyl sulfate in aqueous medium. Colloid Surf B: Biointerfaces 2005;41:209-16.

[12] Panella L, Broos J, Jin J, Fraaije MW, Janssen DB, Jeronimus-Stratingh M, Fering BL, Minnaard AJ, de Vries JG. Merging homogeneous catalysis with biocatalysis: papain as hydrogenation catalyst. Chem Commun 2005;45:5656-8.

[13] Szabó A, Kotórman M, Laczkó I, Simon LM. Spectroscopic studies of stability of papain in aqueous organic solvents. J Mol Catal B: Enzym 2006;41:43-8.

[14] Lou W-Y, Zong M-H, Smith TJ, Wu H, Wang J-F. Impact of ionic liquids on papain: an investigation of structure-function relationships. Green Chem 2006;8:509-12. 
[15] Lang A, Hatscher C, Kuhl P. Papain-catalysed synthesis of Z-L-aminoacylantipyrine amides from $Z$-protected amino acid esters and 4-aminoantipyrine. Tetrahedron Lett 2007;48:3371-4.

[16] Szabó A, Kotormán M, Laczkó I, Simon LM. Improved stability and catalytic activity of chemically modified papain in aqueous organic solvents. Process Biochem 2009;44:199-204.

[17] Zhang Y, Shi G, Zhao F. Hydrolysis of casein catalyzed by papain in npropanol/NaCl two-phase system. Enzyme Microb Technol 2010;46:438-49.

[18] Wang M, Jia C, Qi W, Yu Q, Peng X, Su R, He Z. Porous-CLEAs of papain: application to enzymatic hydrolysis of macromolecules. Bioresour Technol 2011;102:3541-5.

[19] Jackson M, Mantsch HH. The use and misuse of FTIR spectroscopy in the determination of protein structure. Crit Rev Biochem Mol Biol 1995;30:95-120.

[20] Goormaghtigh E, Cabiaux V, Ruysschaert JM. Secondary structure and dosage of soluble and membrane proteins by ATR-FTIR on hydrated films. Eur J Biochem 1990;193:409-20.

[21] Morcelle SR, Barberis S, Priolo N, Caffini NO, Clapés P. Comparative behaviour of proteinases from the latex of Carica papaya and Funastrum clausum as catalysts for the synthesis of Z-Ala-Phe-OMe. J Mol Catal B: Enzym 2006;41:117-24, and references therein.

[22] Llerena-Suster CR, Obregón WD, Trejo SA, Morcelle SR. Papain purification insights: monitoring by electrophoretic approaches and MALDI-TOF peptide mass fingerprint analyses. Anal Lett 2011;44:2124-37.

[23] Llerena-Suster CR, Priolo NS, Morcelle SR. Sodium tetrathionate effect on papain purification from different crude extracts obtained from Carica papaya latex. Prep Biochem Biotechnol 2011;41:107-21.

[24] Priolo N, López LMI, Arribére MC, Natalucci CL, Caffini NO. New purified plant proteinases for the food industry. Acta Aliment 1991;20:189-96.

[25] Bradford MM. A rapid and sensitive method for the quantitation of microgram quantities of protein utilizing the principle of protein-dye binding. Anal Biochem 1976;72:248-54.

[26] Kamphuis IG, Kalk KH, Swarte MBA, Drenth J. Structure of papain refined at 1.65 Å resolution. J Mol Biol 1984;179:233-56.

[27] Schechter I, Berger A. On the size of the active site of proteases. I. Papain. Biochem Biophys Res Commun 1967;27:157-62.

[28] Ménard R, Storer A. Papain. In: Barrett A, Rawlings ND, Woessner JF, editors. Handbook of proteolytic enzymes. London: Academic Press; 2004. p. 1126.

[29] Fernandez MM, Margot AO, Falender CA, Blanch HW, Clark DS. Enzymatic synthesis of peptides containing unnatural amino acids. Enzyme Microb Technol 1995; $17: 964-71$.

[30] Shen H-Y, Tian G-L, Ye Y-H, Wang J. Non-coded amino acids as acyl donor substrates for peptide bond formation catalyzed by thermoase in toluene. J Mol Catal B: Enzym 2005;37:26-9.

[31] Cantacuzène D, Pascal F, Guerreiro C. Synthesis of amino acid esters by papain. Tetrahedron 1987;43:1823-6.

[32] Fernández MM, Clark DS, Blanch HW. Papain kinetics in the presence of a watermiscible organic solvent. Biotechnol Bioeng 1991;37:967-72.

[33] Fité M, Alvaro G, Clapés P, López-Santín J, Benaiges MD, Caminal G. Reactivity of easily removable protecting groups for glycine in peptide synthesis using papain as catalyst. Enzyme Microb Technol 1998;23:199-203.

[34] Stehle P, Bahsitta H-P, Monter B, Fürst P. Papain-catalysed synthesis of dipeptides: A novel approach using free amino acids as nucleophiles. Enzyme Microb Technol 1990;12:56-60.

[35] Stevenson DE, Storer AC. Papain in organic solvents: determination of conditions suitable for biocatalysis and the effect on substrate specificity and inhibition. Biotechnol Bioeng 1991;37:519-27.
[36] Clapés P, Torres JL, Adlercreutz P. Enzymatic peptide synthesis in low water content systems: preparative enzymatic synthesis of [Leu]- and [Met]-enkephalin derivatives. Bioorg Med Chem 1995;3:245-55.

[37] Morcelle SR, Liggieri CS, Bruno MA, Priolo N, Clapés P. Screening of plant peptidases for the synthesis of arginine-based surfactants. J Mol Catal B: Enzym 2009;57:177-82.

[38] Rival S, Saulnier J, Wallach J. On the mechanism of action of pseudolysin: kinetic study of the enzymatic condensation of Z-Ala with Phe- $\mathrm{NH}_{2}$. Biocatal Biotransform 2000;17:417-29.

[39] Tai D-F, Fu S-L, Chuang S-F, Tsai H. Papain catalyzed esterification in polar organic solvents. Biotechnol Lett 1989;11:173-6.

[40] Gebhard LG, Carrizo FU, Stern AL, Burgardt NI, Faivovich J, Lavilla E, Ermácora MR. A Kazal prolyl endopeptidase inhibitor isolated from the skin of Phyllomedusa sauvagii. Eur J Biochem 2004;271:2117-26.

[41] Potetinova JV, Voyushina TL, Stepanov VM. Enzymatic síntesis of peptidy amino alcohols and peptidyl amino aldehydes-serine proteinase inhibitors. Bioorg Med Chem 1999; 7:705-10.

[42] Bacheva AV, Filippova IY, Lysogorskaya EN, Oksenoit ES. Stability and catalytic properties of subtilisin in acetonitrile/dimethylformamide mixtures with low water content. J Mol Catal B: Enzym 2000;11:89-96.

[43] Kijima K, Yamamoto S, Kise H. Study on tryptophan fluorescence and catalytic activity of $\alpha$-chymotrypsin in aqueous-organic media. Enzyme Microb Technol 1996;18:2-6.

[44] Herlax V, Bakás L. Fatty acids covalently bound to R-hemolysin of Escherichia col are involved in the molten globule conformation: implication of disordered regions in binding promiscuity. Biochemistry 2007;46:5177-84.

[45] Barth A. Infrared spectroscopy of proteins. Biochim Biophys Acta 2007;1767:1073-101.

[46] Dong A, Matsuura J, Allison JD, Chrisman E, Manning MC, Carpenter JF. Infrared and circular dicroism spectroscopic characterization of structural differences between $\beta$-lactoglobulin A and B. Biochemistry 1996;35:1450-7.

[47] Kong J, Yu S. Fourier transform infrared spectroscopic analysis of protein secondary structures. Acta Biochim Biophys Sin 2007;39:549-59.

[48] Barth A, Zscherp C. What vibrations tell us about proteins. Q Rev Biophys 2002;35:369-430.

[49] Natalello A, Ami D, Brocca S, Lotti M, Doglia SM. Secondary structure, conformational stability and glycosylation of a recombinant Candida rugosa lipase studied by Fourier-transform infrared spectroscopy. Biochem J 2005:385:511-7.

[50] Haris PI, Severcan F. FTIR spectroscopic characterization of protein struc ture in aqueous and non-aqueous media. J Mol Catal B: Enzym 1999;7: 207-21.

[51] Foresti ML, Valle G, Bonetto R, Ferreira ML, Briand LE. FTIR, SEM and fracta dimension characterization of lipase B from Candida antarctica immobilized onto titania at selected conditions. Appl Surf Sci 2010;256:1624-35

[52] Lau RM, Sorgedrager MJ, Carrea G, van Rantwijk F, Secundo F, Sheldon RA. Dissolution of Candida antarctica lipase B in ionic liquids: effects on structure and activity. Green Chem 2004;6:483-7.

[53] Oberg KA, Ruysschaert JM, Goormarghtigh E. Rationally selected bases proteins: a new approach to selecting proteins for spectroscopic secondary structure analysis. Protein Sci 2003;12:2015-31.

[54] Tremmel S, Beyermann M, Oschkinat H, Bienert M, Naumann D, Fabian H. ${ }^{13} \mathrm{C}$-Labeled tyrosine residues as local IR probes for monitoring conformational changes in peptides and proteins. Angew Chem Int Ed 2005;44: 4631-5.

[55] Bordusa F. Proteases in organic synthesis. Chem Rev 2002;102:4817-67. 